\section{考察および結語}

1) 1984 年以降の補助循環症例 18 例中, 11 例が離脱 に成功し (61.1\%)，6 例が生存している $(33.3 \%) .2)$ 体外循環離脱後の緊急使用には, 当初の両心補助の必要 性から屯左心バイパス移行型両心バイパス法が優れてい たが，3日以上におよぶ場合は，さらに LVADへの移 行が必要之考えられた．3）初期の DVB 中は自己心の 仕事量を抑えるために, 総灌流量近くの流量で補助し, IABP を併用する. Systolic unloading と末梢循環保持 の目的で血管挔張剤の使用が望ましい。カテコラミンは 左室の容量負荷の可能性を考慮し，自己心が駆出できる 程度には使用したほうがよいようである。右心機能の回 復が期待できるときは，中心静脈圧等に注意しながら右
房の脱血チューブを少しずつクランプし，完全にクラン プした状態で灌流量を $1 / 3$ 亿減量し，適当なカテコラミ ン量で右心不全, 左心不全の徴候がでなりれば LVB へ 移行し，安定した時点で人工肺，リザーバーを除いて， 閉鎖回路とする.4）VAB の特徵は左心の前負荷軽減効 果が不十分であるとともに，左心の後負荷が増強する場 合が多くみられることである，そのため，左心機能が比 較的良好で，短時間の補助で離脱できる症例に対して， 適応すべきと考えられた．5）最近の心筋保護法, 術後 管理法の進歩とと屯に，補助人工心臟の進歩は，開心術 の限界を大きく拡大しつつある. 当科の LVAD 症例 む, LVAD stand-by の条件下で手術にふみきった 10 例以上に招上ぶ開心術限界症例の 2 例であった。

\title{
31 補助循環に関する実験的および臨床的検討
}

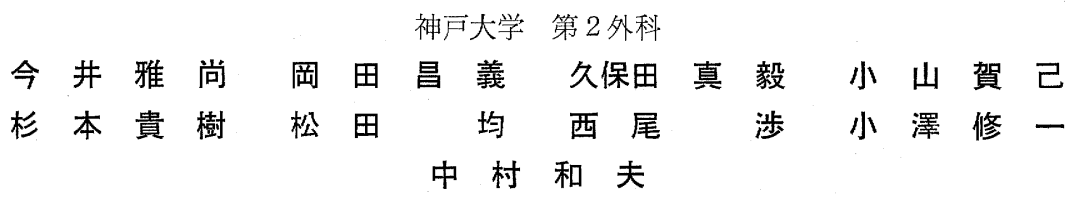

心筋梗塞後の心原性ショックや開心術後の重症 LOS 症例には，現在薬物療法に加えて IABP が積極的に応 用されている．しかし，本法が無効な症例にはより強力 な補助循環法が必須となる1 3). 今回，珈る重症例の 救命を企図し，実験的に左心不全を作成し，遠心ポンプ (Bio-Pump) を用いる左心バイパス (Left heart bypass : LHB）を実施し，バイパス流量の変化に伴う早期の血行 動態について検討を加えたので報告する．また，補助人 工心葴 (ventricular assist device : VAD) を用いた臨床 例についてああわせて報告する。

\section{対象ならびに研究方法}

雑種成犬 18 頭を用いて, 左冠動脈の前下行枝の末梢 1/3 と対角枝を含む multiple ligation により広範な心 筋梗塞を作成しショョック陥った時点で LHB を開始 した. バイパス流量により, バイパス流量を LHB 開始 直前の $1 / 2$ としたI 群, バイパス流量を各時点において full としたII群，不全心作成後，LHB を実施しなかっ た监群に分類した．また，LHB の方法は左房より脱血
し，左鎖骨下動脈または大腿動脈より送血した。

\section{研 究 成績}

まず，III群では進行性の心不全を呈し，90 分以内(平 均 48 分) 飞全例が死亡し, 広範梗塞の予後の不良なこ とが示された（図 1)。な招，LHB 実施中のバイパス率 はI群で平均 $46 \%$ ，II群で $84 \%$ であった。

平均動脈圧は不全心の作成により，I， II群でそ机ぞ れ $104 \rightarrow 72 \mathrm{mmHg}(31 \%$ 減少), $102 \rightarrow 74 \mathrm{mmHg}(27 \%$ 減少) と低下したが，LHB の開始により，それぞれ 72 $\rightarrow 80 \mathrm{mmHg}$ (11\% 増加), $74 \rightarrow 93 \mathrm{mmHg}$ (26\% 増加) と上昇し，II群ではその後む $90 \mathrm{mmHg}$ 以上の良好な血 圧を維持した。また，LAP (mean) は不全心の作成によ って，I， II 群でそれぞれ平均 $8 \rightarrow 14 \mathrm{mmHg}, 9 \rightarrow 12$ $\mathrm{mmHg}$ へ上上昇したが，バイパス開始後は両群でとも 亿低い值を維持した（図1).

LVP は不全心の作成後は I, II 群とむに低下したが, LHB の開始により，I群では有意な変化はみられなか ったが，II群では減少傾向が認められた。一方，LV开 

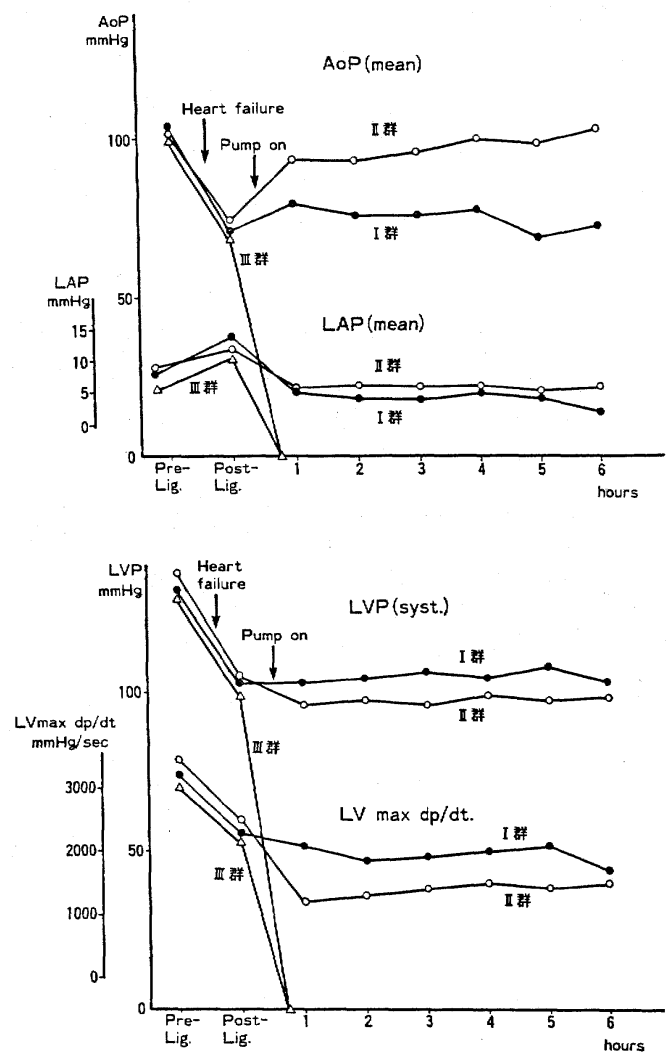

図 1 不全心に対する LHB (Bio-Pump) 中の血行動態の 推移

$d p / d t$ は不全心の作成後は，I， II群とあに低下し， LHB の開始により，I，II群でそれぞれ平均 2300 $\rightarrow$ $2100 \mathrm{mmHg} / \mathrm{s}$ (9\% 減少)，2500 $\rightarrow 1300 \mathrm{mmHg} / \mathrm{s} \quad(48 \%$ 減少) とI群に比し，II群で著明な低下がみられ心補助 効果が認められた (図1).

\section{臨床的研究}

症例 1 : 68 歳女性, 急性心筋梗塞に心室中隔穿孔を 合併したショック症例である. IABP 実施下に, 穿孔部 閉鎖と回旋枝への bypass を緊急的に行ったが，体外循 環からの離脱が不可能なため, left ventricular assist device (LVAD, 東洋紡製) に移行した。術後経過はお おむね順調で術後 7 日目に LVAD，続いて IABP より 離脱しえた，その後小康状態を得ていたが，㛑不全を併 発し, 結局, 術後 24 日目に MOF で失った(図2).

症例 $2: 46$ 歳男性, 21 年前に僧帽弁交連切開術をう けた重症連合弁膜症例 (MS+AR+TR) である. 術前検 査で \%FS は $21 \%, \mathrm{CI}$ は 2.0 と高度の左心機能低下が

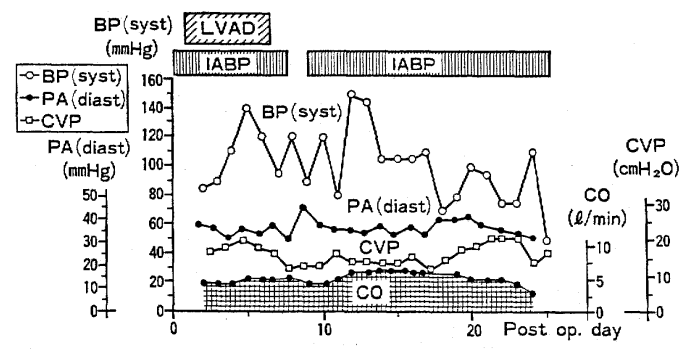

図 2 LVAD 抒よび IABP 実施中の血行動態の推移 (68歳女性)

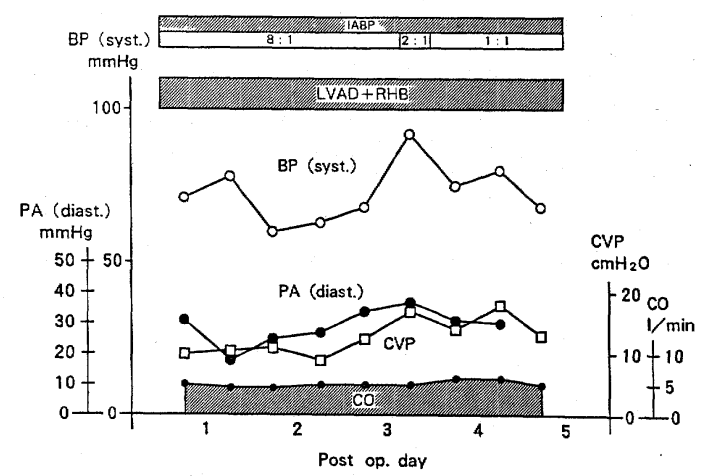

図 3 LVAD+RHB (右心バイパス) 実施中の血行動態 の推移 (46歳男性)

認められ，糖㽷病と中等度の肝機能障害を合併してい た. 手術は MVR+TAP が円滑に実施されたが，体外 循環からの離脱が不可能なため, II度の $\mathrm{AR}$ 病変に対 して AVR を追加した. しかし，大量のカテコラミン投 与や IABP を併用しても改善されないため, ただちに, LVAD Kローラーポンプを用いた右心バイパスを加え た両心バイパスを行い，ようやく体外循環から離脱しえ た. 術後は一時, 小康状態を得ていたが, 結局, 術後 5 日目に脸障害を併発し死亡した（図 3 ).

\section{考察}

LVAD は左室圧負荷の軽減や counterpulsation 効果 を備えており，強力な心補助手段といえる. しかし，不 整脈を伴った症例や小児開心術例では心拍動に同期させ るととが困難である. 一方, 定常流が得られる遠心ポン プは容量負荷軽減の大きな効果があり, 不整脈や頻脈時 であ容易に使用可能である.

また, 犬の冠動脈は collateral が発達しており, 左冠 動脈の数本の結紮だけでは確実な心筋梗塞が得られない ことが多い，そこでわれわれは左冠動脈の前下行枝之対 角枝および周囲の collateral を含めた multiple liga- 
18: 118

日本心臟血管外科学会雑誌 18 巻 1 号 (1988)

tion を行うことによりショックを伴う心筋梗塞を作成 することができた，事実，上述の方法で心筋梗塞を作成 するのみで LHB を実施しなかった正群ではてのショッ ク状態から離脱しえず, 平均 48 分で死亡した. このよ うに亚群では LHB を実施したI, II群と対比し, 非常 にミゼラブルな経過をたどったととは，LHB の有効性 が示唆されたものといえる.

本研究では full bypass を行ったII群でのバイパス率 は $84 \%$ に達し, 容量負荷を十分隹減することができ たものと考えられた。また， $\mathrm{LV}_{\max } . d p / d t$ は $48 \%$ の減 少, AoP (mean) は $26 \%$ の増加を認めたてとから, Bio-Pump による左心バイパス法によっても，十分な心 補助効果と末梢循環の改善の得られることが認められ, 臨床応用への可能性が示唆された.

一方, LVAD を用いた臨床例においても, 症例 1 で は経時的に血行動態の著明な改善ならびに心機能の回復
がみられ，LVAD の有用性が十分示されたあのと考え られた，また症例 2 でみられたように，両心不全に対し 両心バイパスを行う場合, 定常流による右心バイパスに よっても臨床的に十分対応しうるものと考えられた。

\section{結語}

1）不全心に対する左心バイパス法は実験的および臨 床的に有効であることが確認された。

2) 左心バイパス中, とくに full bypass 法で優れた 心補助効果之末梢循環の改善が認められた。

文献 1) Pae, W. E. et al.: J. Thorac. Cardiovasc. Surg. 93: 434, 1987, 2) 岡田昌義: 臨床胸部外科 7:230, 1987. 3) Okada, M. et al.: Presented at 2 nd International Symposium on Artificial Heart and Assist Device 13, August, Tokyo, 1987. 